Vol. XX, No. 1

\title{
Annual Report on the Whooping Crane Population
}

by Fred G. Bard, Director, Saskatchewan Museum of Natural History

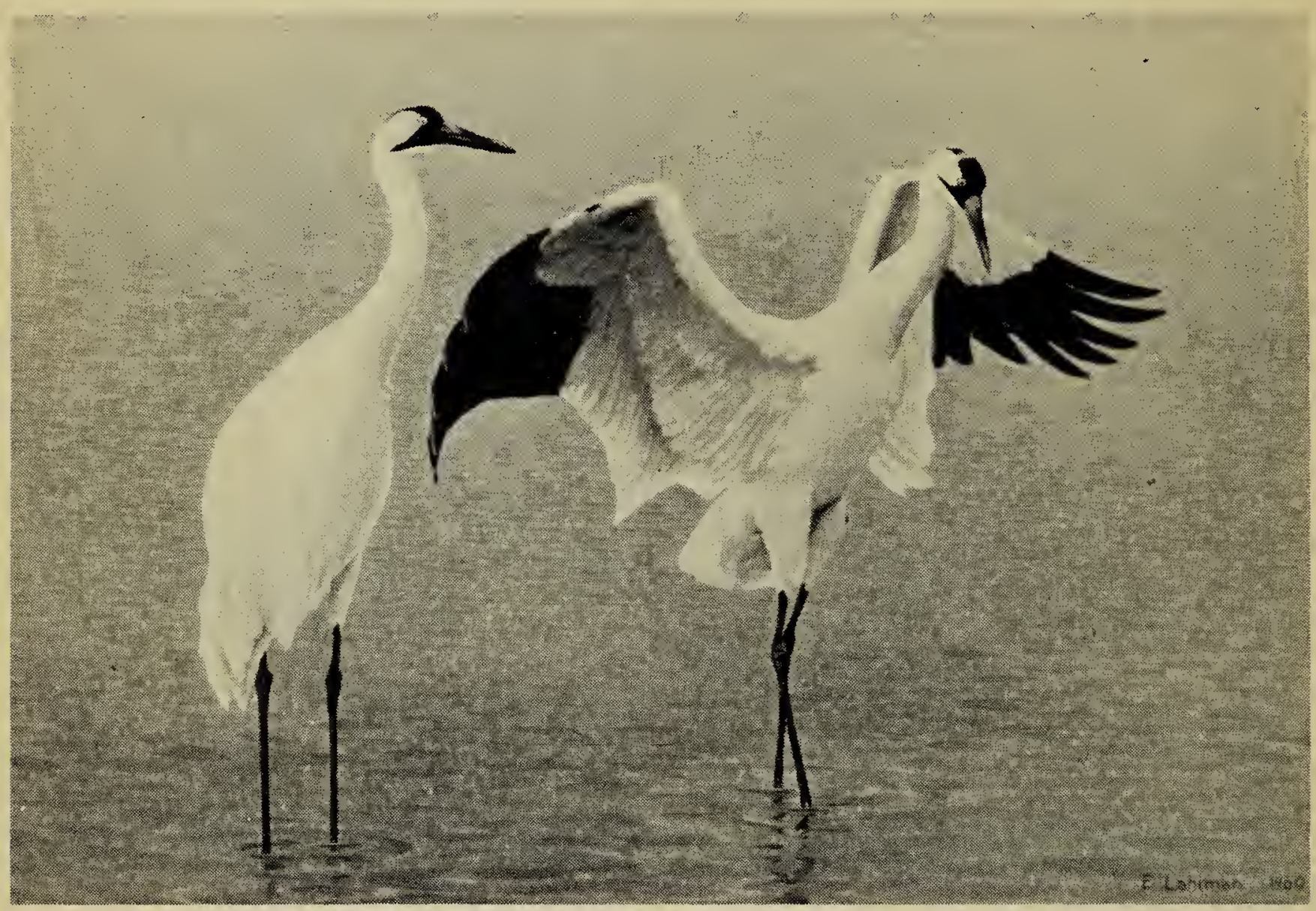

Painting by $F$. W. Lohrman Courtship Behaviour of the Whooping Crane, Aransas Refuge, 1960.

We know that readers of the Blue Jay like to have a brief report each year on the current status of the Whooping Crane population. This time there are two items of interest to report. In the first place, we know that 38 cranes are wintering at the Aransas National Wildlife Refuge this season. According to the report received from E. E. Crawford of the Branch of Wildlife Refuges, U.S. Fish and Wildlife Service, the 1961 arrivals from the north included five young of the year, but three adults were missing. The first Whooping Crane was sighted at the Aransas Refuge on October 15, and it was believed that it had arrived on October 14 when a cold front was reporting moving across the state. Before this date, an encouraging number of sightings along the flyway had been reported, and we should like to thank especially those who sent in reports to the Saskatchewan Museum of Natural History. It was not possible for us to go out from the Museum to field-check all these observations, but it is important for us to have the reports to get a general picture of the migration of the Whooping Crane. We urge you all to send any reports of Whooping Cranes observed in spring migration, 1962, to the Saskatchewan Museum of Natural History.

The Aransas Refuge, winter headquarters of the Whooping Cranes and the men who study them, now has on display a painting of the cranes in flight done by Museum artist Fred W. Lahrman. This painting was presented to the Refuge Manager, Huyson J. Johnson, by the Saskatchewan Department of Natural Resources at a conference of refuge managers held January 15-19 at Albuquerque, New Mexico.

The second item of interest is that a young crane has been raised in captivity this year at the Audubon Park Zoo in New Orleans, where 
George Douglass is the superintendent. Parents are the world-famous Crip and Josephine, who have now raised four offspring, including the eight-month-old "Pee-Wee" that hatched last April. This means that there are now six birds in captivity in the Audubon Park Zoo. Fred Lahrman and I hope to see the young crane on our trip south next month.

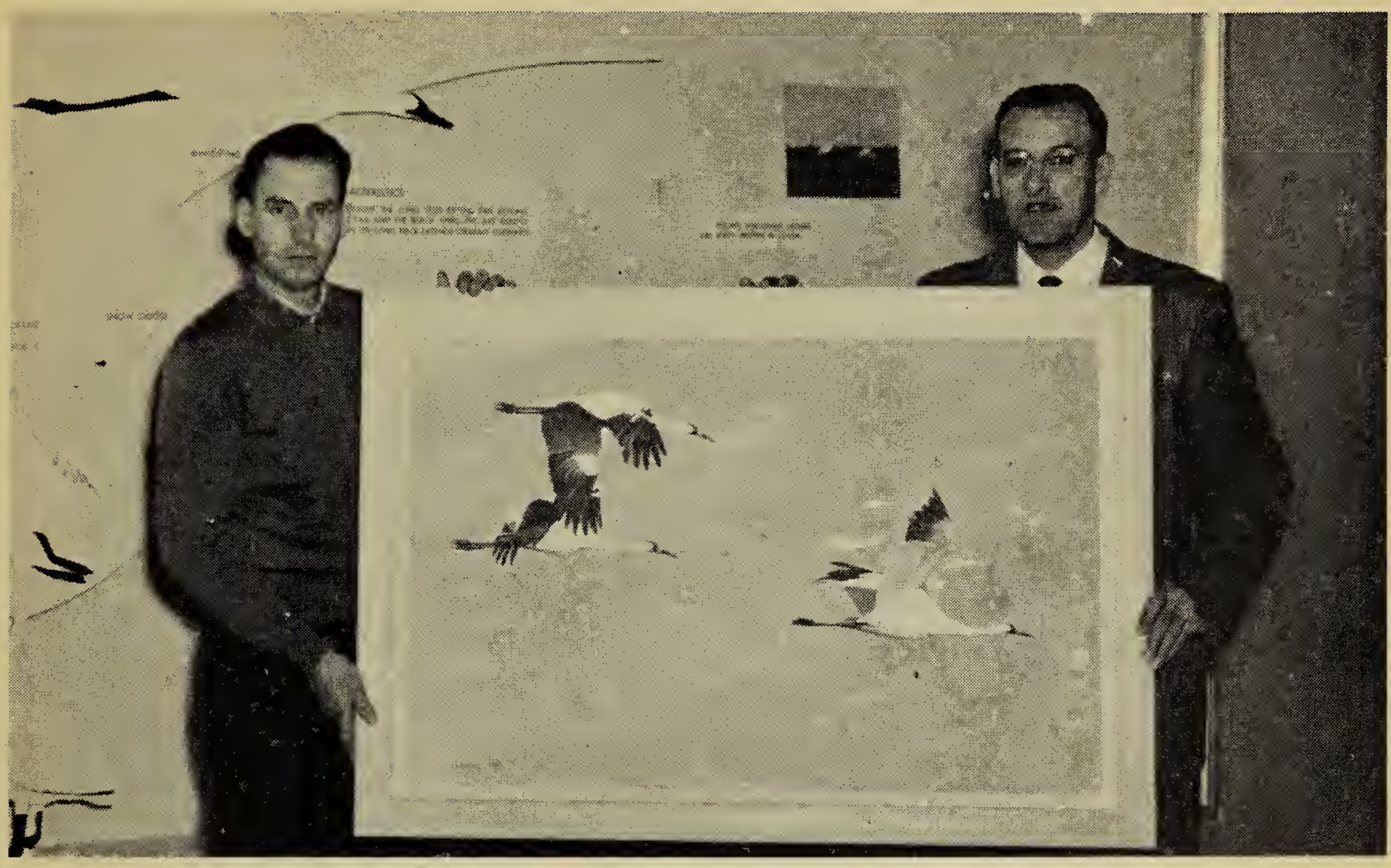

S.M.N.H. Photo

Fred Lahrman (on the left) and the author hold the painting by Lahrman presented to the Aransas Refuge by D. N. R.

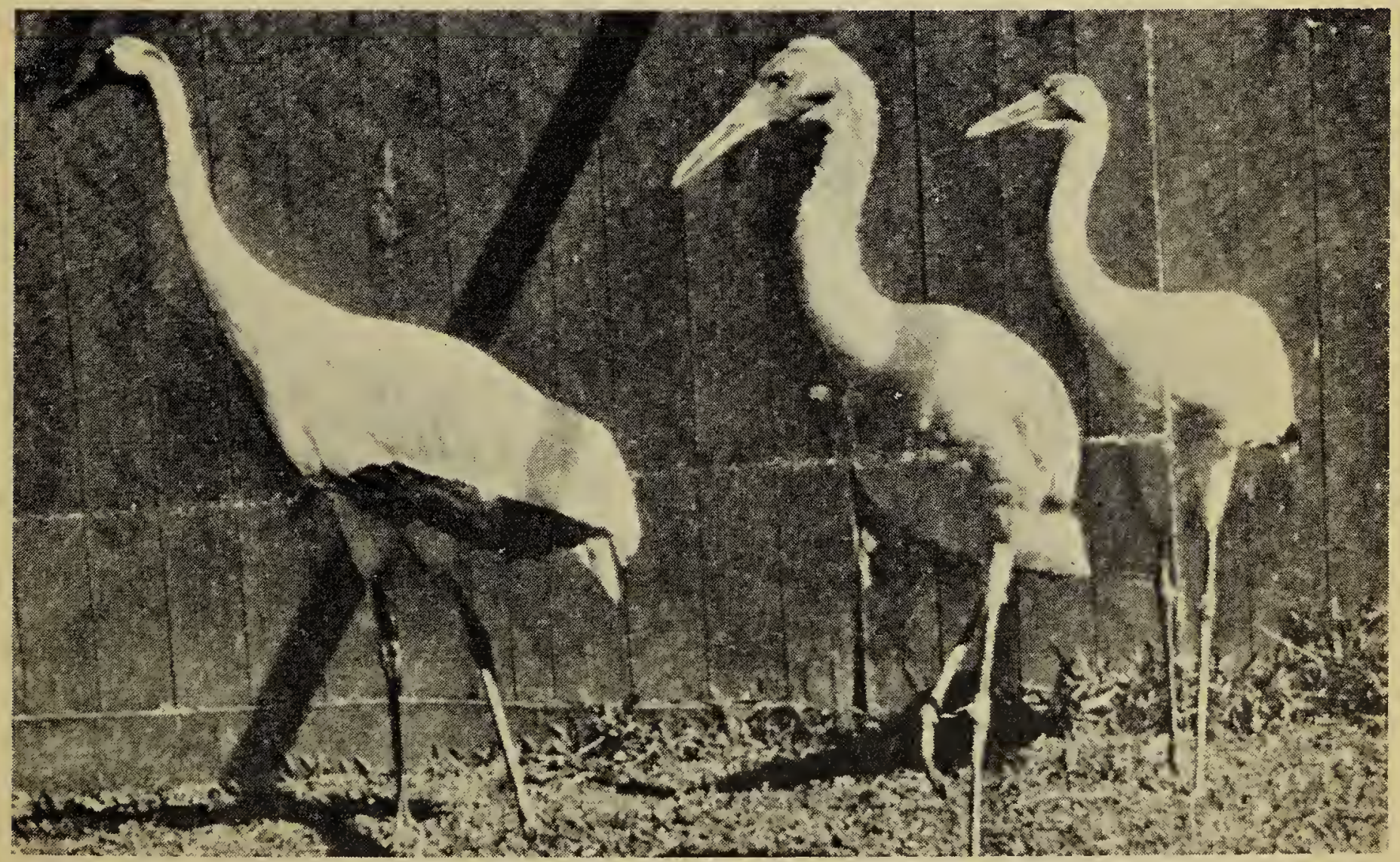

Reprinted from Dixie Magazine Young crone ot Audubon Park Zoo, New Orleans. 